\title{
Improvement of Model Student Learning Through The Content of Solutions Guided Discovery Buffer
}

\author{
Iswan Setiadi ${ }^{1}$, Yudha Irhasyuarna ${ }^{2}$ \\ ${ }^{1}$ Program Master of Natural Science Education of Lambung Mangkurat University; iswan.setiadi@ gmail.com \\ ${ }^{2}$ Chemical Education of Lambung Mangkurat University
}

\begin{abstract}
Difficulties in learning chemistry for this still dwell on the difficulty in delivering of material that is abstract and microscopical. Lack of student understanding of abstract concepts of chemistry led to higher student outcomes on algorithmic aspects rather than its conceptual aspect. The study was to observe at student learning and trying to improve learning results in the subject matter of the buffer solution that it includes abstract concepts and contextually closely connected with algorithmic. The subject is a 21 pupils in class XI IPA 1 SMA Muhammadiyah Banjarmasin. This study aims to determine the increase (1) the activities of teacher, (2) the activity of students, (3) learning outcomes, and (4) the students' responses. The study design was a Class Action Research (CAR) and the study finished after reaching classical completeness in the second cycle to the research stages of planning, action, observation and reflection. The research instrument is a test and non-test. Data were analyzed by using quantitative descriptive analysis. The results showed that an increase in the sector (1) the teacher's activities is $7.68 \%$, (2) the activity of students is $11.08 \%$, (3) cognitive achievement of students is $33.33 \%, 11.00 \%$ process skills, psychomotor learning outcomes is $11.20 \%$, affective learning outcomes by $30.01 \%$, and (4) the response of students in the learning process guided discovery aided macromedia flash showed positive results with the percentage of $80.95 \%$. The other findings are students easier in solving algorithmic problems than students completing the conceptual thus corroborates previous studies.
\end{abstract}

Keywords: learning outcomes, guided discovery, a buffer solution

\section{Introduction}

Chemistry is a branch of science that allows students to understand what is happening around them that is represented in the form of abstract processes and relate to the basic structure of matter, so it becomes one of the difficult subject matter (Sirham, 2007). Difficulty in understanding the chemistry subject matter is considered because there are many unfamiliar abstract concepts to students (Treagust and Chittleborough, 2001). Teacher often explain the subject matter in chemistry using a variety of molecular formula, chemical equation, and the various processes that occur in the microscopic level and abstract concepts using symbols that are difficult to understand students without reaching the contextual aspect.

As an example of this is the subject matter of buffer solution. The character of the buffer solution is abstract (acid-base reactions), conceptually understanding (nature buffer solution), and real and applicable (the role of buffer solution) so that the learning requires tangible teaching to the abstract concept that can be evidenced by appropriate methods (Arnas, 2012). Prerequisites for studying the materials of the buffer solution is that students are required to have basic knowledge of substances that are classified as strong acids, weak acid, strong base, weak base. This knowledge will facilitate students how a reaction between a weak acid with the conjugate base or a weak base with its conjugate acid to produce a salt with a $\mathrm{pH}$ which is not too far away with the $\mathrm{pH}$ of a weak acid or weak base. However, if the teaching only in the form of concepts, it won't be enough. When teacher want to educate students in the higher level, meaningful learning will arise if the student is able to understand not only remembering facts theoretically.

Based on the experience of researcher when conducting observations in a non-governal high school in Banjarmasin, applied learning is still centered on the teacher (teacher-centered) so that students experience a deadlock in understanding the concepts being taught and fast experience boredom in learning. Conditions like this will make students easy to forget the lessons and student activties evaluation toward information they receive is still less because they do not understand the material being taught. Worse, this kind of learning is practiced to guide students to memorize and understand the chemical processes through the separated concept. Not surprisingly, students are better able to operate on a formula than trying to explain a concept for operational ease formula or equation is applicable. Reflection on learning is done, and obtained in good results but the cognitive learning of students but they do not understand chemistry that is taught. This could happen if they are tested to find academic achievement algorithmic problems more than a matter of conceptual and contextual. In line with the statement in fact there are many students who have difficulty in understanding a concept of chemistry. Haláková and Prokša (2007) revealed that students often reveal the right answer even without understanding the contents of a question, and not even accompanied by a logical and reasonable explanation. 
Boo (1998) in Treagust and Chittleborough (2001) reveals the unique problems in chemistry learning in school is an anomaly where in fact the students were able to answer specific questions related to the concept of chemical bonds without having to understand the overall conception.

The problems related to students' cognitive learning outcomes will be assessed as pass during the exam, but if judged qualitatively the the result will be opposite and will not last long (short term memory). Learning process needs to reform so that students are able to understand the whole chemistry knowledge not only a part of which is reflected from the proportional achievement test. The Proportional understanding in terms of conceptual and algorithmic should be balance and able to connect both of them. One example comes from research solution Osman and Sukor (2013) which explains that the chemistry teacher should use alternative strategies, such as constructivism and cognitive scaffolding to help students understand and remediate the concepts of the students.

The subject matter of the buffer solution is one of quite complex the materials because it contains the chemical reaction, the basics of acid-base, titration process, the process of inertia $\mathrm{pH}$, and appliance in everyday life. Learning like this need to be operated with a model that can accommodate and can be applied in these conditions. Development of the students absorption can be done by increasing the activity of thinking students to understand the material and concepts being taught, it can be done by increasing the active involvement of students. The active involvement of students allows them to learn the concepts and principles from themselves, and learn to solve problems independently through the investigation (Suyidno, 2012). Activities of the students can be found through appropriate learning models. The use of appropriate learning models can enhance students' interest in learning and motivation in order to provide convenience for students to learn to improve learning outcomes. One of the learning model that supports the active involvement of students and constructivistism is guided discovery learning model (guided discovery learning). According to Klahr and Nigam (2004), that in science learning models use the invention as opposite to the direct learning will produce a deep and lost longer understanding in students. According to Sund (1973), the discovery occurs when an individual is involved, especially in the use of mental processes to find some of the concepts and principles. The active involvement of students in learning allows them to learn the concepts and principles from themselves, and learn to solve problems independently through the investigation.

Saefulbahri (2015) in his research guided discovery explains that the model is able to improve learning outcomes significantly. Alfieri, et al. (2011) found that the model of the discovery (discovery) without guidance the results are no better than direct instructional learning to student learning, so it is recommended to use the model of guided discovery in which there is feedback, pilot, scaffolding and explicit instruction. Victoria and Paul (2014) states that the model guided discovery that integrates seamlessly with the concept of mind mapping has good effectiveness in teaching chemistry concepts difficult. This indicates that the guided discovery learning model of cognitive restructuring and connect ideas of the students with knowledge of the existing structure, so it is worth trying to improve the absorption of students, especially in chemistry lessons are often still considered difficult by students.

Representation of materials chemistry lesson is divided into three levels, namely symbolic, microscopic and macroscopic (Gabel, 1998; Gilbert and Treagust, 2008; Johnstone, 2000; Treagust and Chittleborough, 2001). Guided discovery model application can support and facilitate students in understanding the microscopic level and the process used multimedia in the form macromedia flash to orient students on the issue in the beginning of the lesson and provide a fuller explanation at the end of the lesson. According Nurseto (2011) use of media aimed to identify perceptions of students in early learning, to concrete abstract concepts, and presents objects that are too dangerous or difficult or size that is too big or small in the learning environment. Media contains issues that attract students to investigate further. Presentation of the media will make students more interested and motivated to learn. According to Rieber, et al. (2004) in Mayer (2001), many of the advantages of the use of multimedia in teaching but of course learning model used is recommended to use the model of experiential learning.

Based on this background and see the problems occurred necessary appropriate learning models to enthuse pupils and students in learning activities in the material buffer solution, the researchers need to conduct classroom action research. This study was conducted to improve student learning outcomes in the material buffer solution XI IPA 1 SMA Muhammadiyah Banjarmasin 2014-2015 school year.

The purpose of this study to determine the improvement of student learning outcomes through guided discovery model of the material buffer solution through improvements in the sector of activity of teacher and students. This research is expected to provide the following benefits inputs for teacher on the application of learning guided discovery in the subject matter of the buffer solution, as a way for teacher to determine the learning strategies that will be applied, for further development using different types of approaches guided discovery, especially about chemistry learning XI classes in high school, and be considered for teacher in determining the most appropriate learning model so that the learning process becomes more effective. 


\section{Research Methods}

This study was conducted using Classroom Action Research design (CAR). This research carried out through four stages: planning, action, observation and reflection. The data were analyzed by using quantitative descriptive analysis. It is intended to look at the learning outcome and process skills of students in each cycle after a given action followed by reflection at the end of each cycle.Data collection began in February - May 2015 was conducted in classes X IPA Muhammadiyah 1 Banjarmasin. Subjects are 21 students consisted of 5 male students and 16 female students with ability and absorption varies. The instrument used in the form of test are instruments and non-test form observation sheet (teacher activity and student activities), Student Worksheet (LKS) and Worksheet Practicum (LKP), macromedia flash buffer solution, and the student questionnaire responses. Overall devices used already passed the test validation by experts and specialists in their respective fields.

\section{Teacher Activity}

\section{Research Result}

Teacher activity were observed based on the minimum learning activities that must be done by teacher in implementing the actions. Comparison of the percentage increase in the observation of teacher activity, the data obtained was showed in the form of a diagram as shown in Figure 1.

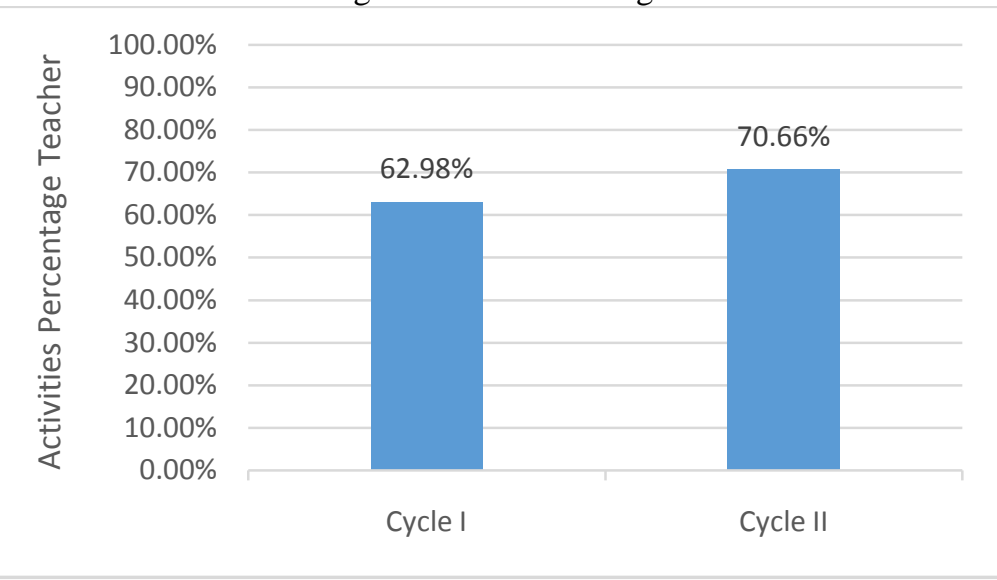

Figure 1 Comparison of percentage of success of the activities of teacher in the first cycle and the second cycle Activities Students

Improvements learning process performed by the teacher are to see the assessment of student activity in the first cycle turns provides enhanced resulting in improved activity of students in the second cycle of this. The increase of percentage observation resulttoward student activity, data obtained was showed in the form of a diagram as shown in Figure 2.

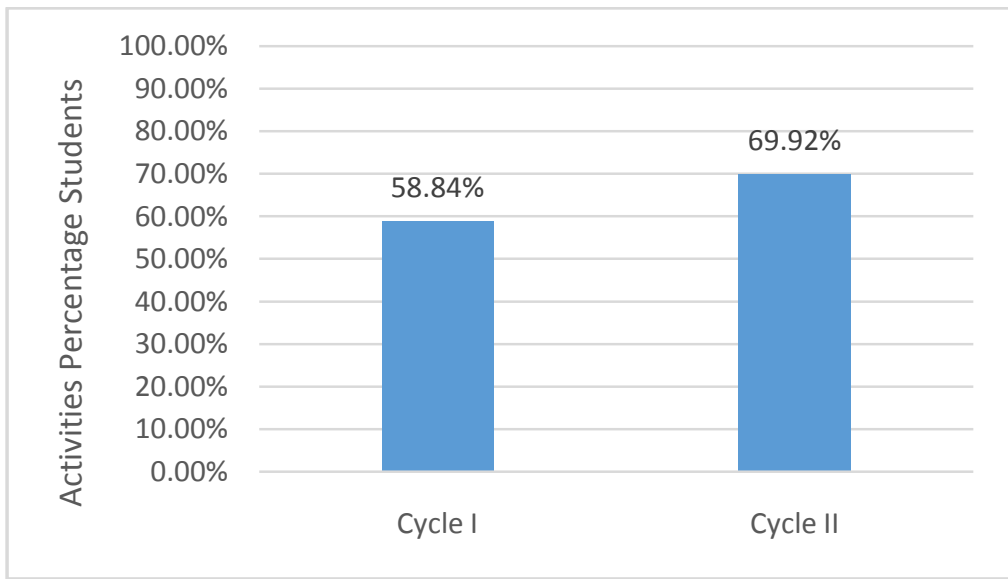

Figure 2 Comparison of the percentage of successful activity of students in the first cycle and the second cycle

\section{Learning Outcomes}

Assessment of learning outcomes include cognitive (cognitive product or process), psychomotor, and affective. The completeness of students' cognitive learning outcomes in the first cycle with a percentage of $42.86 \%$, 
increased in the second cycle into $76.19 \%$. The increase of percentage in success per indicator, the data obtained was showed in the form of a diagram as shown in Figure 3.

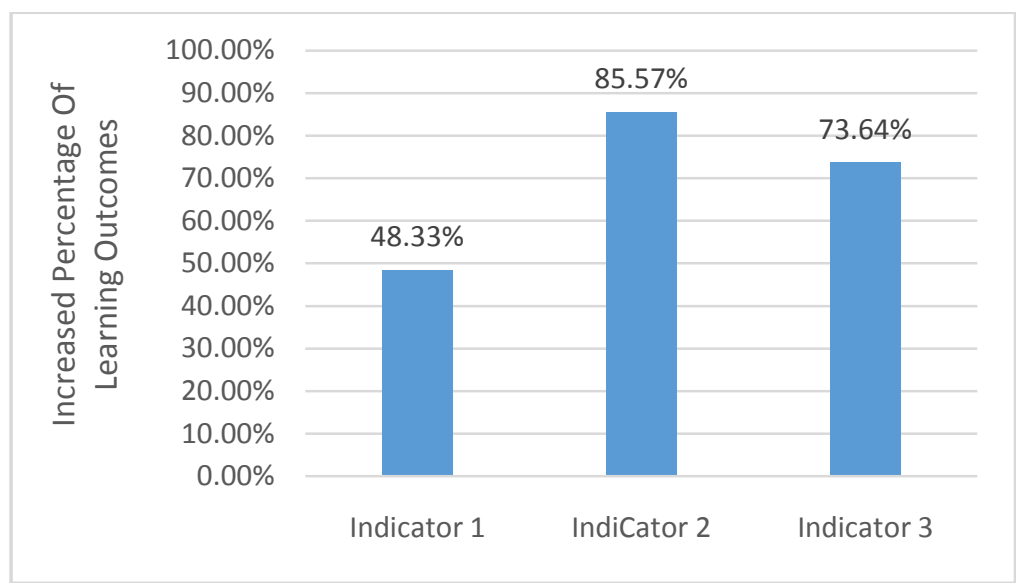

Figure 3 The percentage of success per cycle indicator learning outcomes in the first cycle and the second cycle Students' Process skills are also assessed in this study which is the average value of the first cycle with $66.38 \%$ is considered good enough and increase to $77.38 \%$ in the second cycle with excellent category. The data obtained is processed into a diagram as shown in Figure 4.

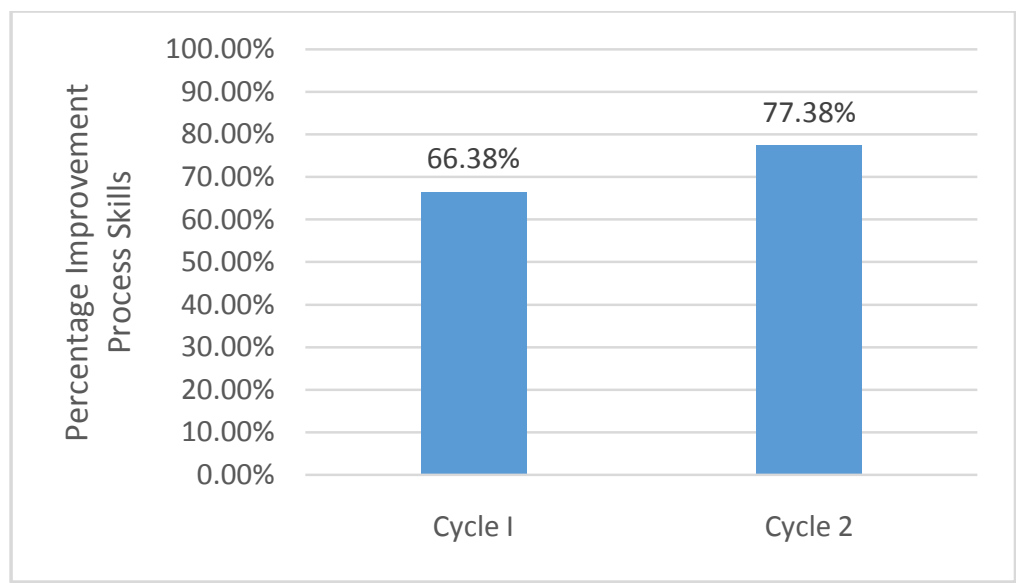

Figure 4 Comparison of the percentage of successful first cycle process skills and cycle II

The increase also occurred in psychomotor students is $11.20 \%$ in both categories at the second cycle. The data obtained is processed into a diagram as shown in Figure 5.

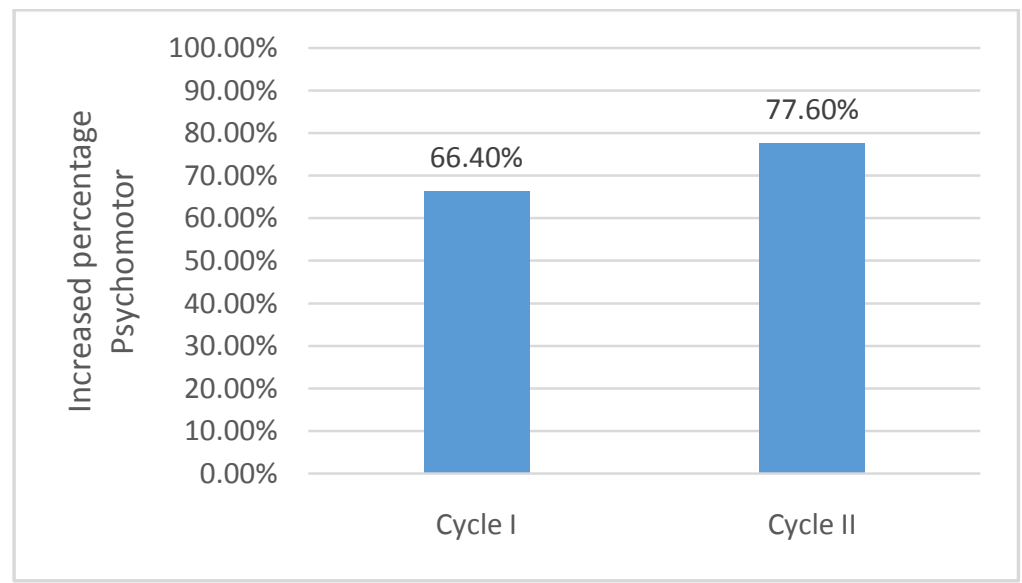

Figure 5 Comparison of psychomotor learning outcomes in both trials in the first cycle and the second cycle 
The significant increase occurred from the first cycle that only $48.56 \%$ to $78.57 \%$ in the second cycle. The percentage of students affective success can be described in Figure 6 below.

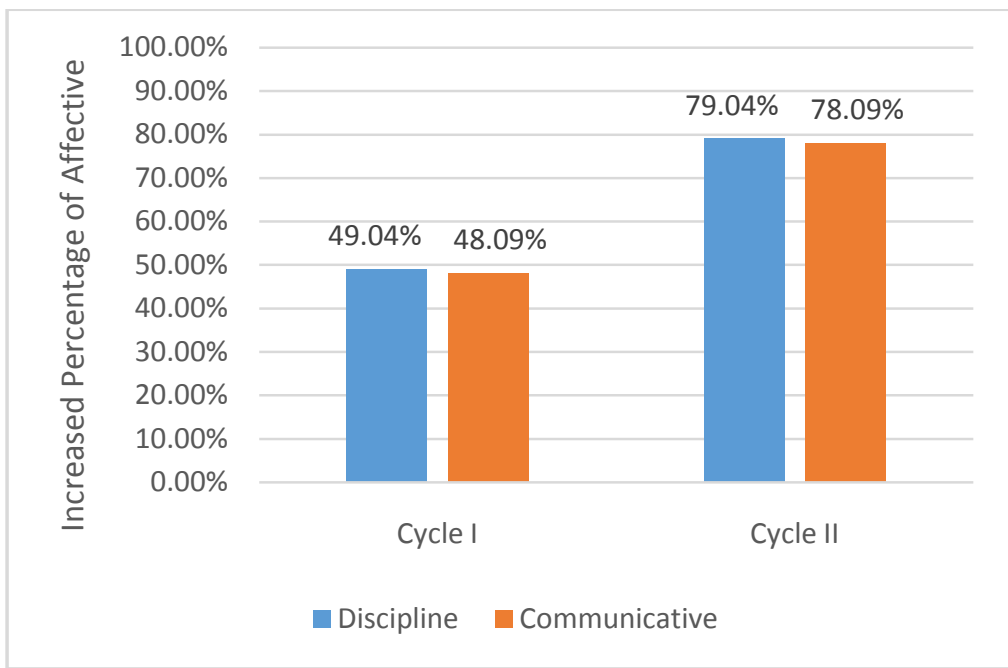

Figure 6 Comparison of affective learning outcomes in both trials in the first cycle and the second cycle

\section{Student Response}

Questionnaire responses were given to the students after learning the second cycle ends. The questionnaire made by researchers with the aim to determine the students' responses to learning a buffer solution with a model of guided discovery with the help of macromedia flash. Learning students' response to the buffer solution through guided discovery learning model with using macromedia flash briefly presented in Table 1.

Table 1 Assessment score student responses

\begin{tabular}{|l|l|l|l|l|}
\hline No. & Score & Frequensies & Students $\mathbf{( \% )}$ & Response Categories \\
\hline 1 & $10-18$ & 2 & 9,52 & Very less \\
\hline 2 & $19-26$ & 0 & 0 & Deficient \\
\hline 3 & $27-34$ & 2 & 9,52 & Sufficient \\
\hline 4 & $35-42$ & 8 & 38,09 & Good \\
\hline 5 & $43-50$ & 9 & 42,86 & Very good \\
\hline
\end{tabular}

\section{Discussion}

There are things that must be considered and corrected by the teacher in first cycle learning, the learning time management problems that can take place in accordance with the plan that has been made. Learning still exceeds the allocated time limit that indicates the ineffectiveness implementation of measures guided discovery learning in cycle I. Another thing to note is learning steps unpatterned when applied in the classroom, the emphasis on how the implementation of the phases of learning based model of guided deiscovery so that students can understand better what is their job at every stages of learning, motivate and monitor the stages of discussion and lead the presentation. Many problems have to be revised when done reflection on the cycle I.

Improvements occurred on learning in the second cycle. Teacher have been carrying out the stages of learning activities in accordance with the plan, which means that the teacher has been able to manage study time well. Teacher also have done systematically guided discovery learning as planned and guidance are performed rated observers have good, effective, and equitable so that errors like in the first meeting of the first cycle is not repeated. This indicated an increase in the percentage of successful activity of the teacher were good enough, increase as number of $7.68 \%$ and categorized as very good. Activities ofteacher in the second cycle is already quite optimal and successful in guiding and directing students in accordance with the planning at the beginning of the second cycle. The whole increase in the activity of teacher in line with the research Jumadi (2013) which stated that teacher need to give more time for students to argue and asked, emphasizing to students to create and write a conclusion, the implementation of learning to manage time so that students get a portion of sufficient time, and motivate students. Increased activity of the teacher does not mean the teacher dominated learning but it indicates the role of the teacher in facilitating learning in the form of guidance thrrough the investigation is going well.

Improvements in teacher's activity would also be an impact on improvement in students' activity. when activities of students viewed as a whole, it showed improvement or significant improvement. Similarly, the activities of the teacher, the first cycle of activity categories of students enter into meaningful activities that both 
active students in the following study was quite good. The teacher felt it herself/hisself that students are looked more proactive especially in experiment, the stages where students are directly involved in seeing and observing chemical changes that occur. This increase explains how to interest students in learning according to research Achera, et al. (2015), personal and independent students are able to explore the concepts being investigated and more responsible in learning.

The focus of this research is on improving student learning outcomes consist cognitive, psychomotor, and affective. when the Cognitive product of students were seen from the indicators, it look good enough in the trend of increasing from the first cycle to the second cycle. Indicator 1 is to analyze the buffer solution and nonbuffer through experiments in the category less the percentage of success of $48.33 \%$. This is due to the majority of students do not develop reasoning and difficult to understand the questions that are conceptual. In addition to the previous learning teacher rarely give problems and exercises similar to the questions on the test results of this study so that students feel difficulty in answering that question. Indicator 2 is to calculate the $\mathrm{pH}$ or $\mathrm{pOH}$ of buffer solution students, the achievement is the highest level of all indicators of success. Students are able to solve better the type of questions that are applicable to the calculation of entering values already known from matter into the equation. Indicator 2 included into thinking low-level / lower order thinking (LOC). Zoller (2007) stated that low-level thinking usually reflects a low level memorization, regurgitation, or the reading of the basic facts, or maybe do one simple step calculation with the help of a calculator. Although it belongs to the low-level thinking, the ability of students to work on algorithmic problems can not be excluded because basically algorithmic chemistry is based conceptually. According Gultepe, et al. (2013) when a student is taught in solving algorithmic chemistry it does not guarantee they also understands conceptually chemistry. Many studies clearly illustrate a gap between students' ability to solve problems counting chemistry with an understanding of the conceptual (Boujaoude \& Barakat, 2000; Cracolice, Deming, \& Ehlert, 2008; Nakhleh, 1993; Niaz, 1995a, 1995b, 2005; Pickering, 1990; Stamovlasis, Tsaparlis, Kamilatos, Papaoikonomou, and Zarotiadou, 2004; 2005 in Gultepe, et al., 2013).

The second cycle there is one indicator that calculates $\mathrm{pH}$ buffer solution with the addition of slightly acidic or slightly alkaline or with dilution. Based on the percentage of achievement toward the third indicators is good because it was quite same as the second indicator about calculting, so students only need to apply the known values of matter into the equation of buffer solution. Of the three items tested, the second item was the lowest in the mastery achievement of student. This shows that students are still accustomed to solve on the problems of non contextual than a matter of contextual. Students are still used to do simple algorithmic problems that can be directly applied to the formula than about algorithmic need reasoning/analysis further. In accordance with the statement Cracolice, et al. (2008) in Gultepe, et al. (2013) that students are better able to solve problems using an algorithmic strategy rather than understand chemistry concepts that are manipulated into algorithmic. Stamovlasis, et al. (2005) stated in his research that the simple algorithmic generate more value higher achievement than algorithmic questions at a higher level and more complex and conceptual questions.

An important phase in this guided learning model is in phase 1 , phase 2 , and phase 3 . Phase 1 orient students to the problems, phase 2 organized students in learning, and phase 3 is investigation guiding individual or group. Thirdly this initial phase was instrumental in the formation of the initial understanding of students, students learn how to plan within a group, and the guidance and direction as how the teacher showed in student investigation. If teacher succeed in givinh a good motivation in the beginning and directionally guiding student then the learning outcomes that was desired finally be achieved. In addition, students also need to be better prepared to receive the lesson well.

The completeness clasically of students in the second cycle already meet the minimum completeness categories which are established by the school with a value $\geq 75$ is equal to $76.19 \%$ better than the first cycle that only $48.56 \%$. Based on a matter of competence tested is more portions of algorithmic problems than conceptual matter so that it is also the important role in boosting student mastery. In addition, guided discovery learning have a positive influence on a student's grade for the guided discovery learning study independently through simple trial and asked questions that are constructing on the concept of the discovery process. Students learn through active participation of those directly related to the application of concepts and conncect it with empirical data through experiments so that they gain experience in itself. This study confirms previous studies that students who learn using guided discovery are better able to answer the questions that tested when compared to traditional teaching methods is seen from the aspect of learning outcomes (Hammer, 1997; Gijlers and Jong, 2005; Unal and Ergin, 2006; Kipnis, 2007 in Balim, 2009).

The assessment are not confined to cognitive products, but also cognitive processes, namely skills during the learning process. Skills processes referred to in this research is the process skills of students based on the investigation and assessed worksheet of each respective group. Based on the classification process skills ability levels of students, the overall average percentage of successful learning process skills at the first meeting of the first cycle was $56.39 \%$, which is in the category of deficient and have not reached the standard classical 
completeness is $75 \%$. The ability of the students in the learning process skills need to be improved in order increased process skills of students exceeds $75 \%$ of the drilled skill aspect.

At the second meeting of the first cycle, process skills students are assessed and obtained the average percentage of success increased by $76.36 \%$. A considerable increase is due to students already trained to investigate to learn from the first meeting. Despite the considerable increase, but there are some aspects which actually decreased, is the indicators to identify problems. Most likely this is the case of students due to lack of students' conceptual understanding and not too familiar with contextual issues. Thus, in the process of doing the worksheets need to be trained in analyzing the problem of what is expressed in the form of a case or discourse.

Process skills students are also assessed in the second cycle. The results of the average percentage of process skills of students has increased quite small but has been categorized as good enough. These data shows that increasing the skills of students already at the limit of optimal so that the overall skills of the students considered as good enough development. This rapid development can not be separated from the role of the teacherthat is very large in orienting students in the beginning of learning, organized into small groups, provide guidance and direction that are fair to each group, guiding class discussions and together with the students summed up the results of learning. Recently the teacher gives his students the evaluation of how the learning has been done. The process of scientific inquiry is able to develop the skills of students' perceptions, so that it can help students understand the process/natural phenomenon in cognitive and physical abilities through active involvement in the learning process (Harlen, 2004; Matson, 2006, in Balim, 2009). Balim (2009) describes in his research how guided discovery capable of making a positive impact in terms of developing the skills of the students.

Psychomotor learning outcomes also showed some pretty good results. Psychomotor skills students are assessed when students perform lab activities/experiments. Psychomotor learning outcomes assessment also follows the category of mastery learning outcomes in which category completeness minimum is 75 . Learning on the first cycle in which students conduct a trial that is at the first meeting. The average percentage of students psychomotor skills was $66.40 \%$ in the category enough. In this first experiment all the student has not reached a score of psychomotor learning outcomes that have been set in using the tools and procedures of planned work students. But the second cycle of the second trial occurred a good improvement at all in which 21 of the students achieve mastery of $100 \%$ with an average percentage of $77.60 \%$ in both categories.

The success is very high in the second cycle for the working procedure done exactly the same as the experiment in the first cycle except in the calculation of the $\mathrm{pH}$ of the buffer solution using a $\mathrm{pH}$ meter is not universal indicator. The activities that have been done of course will make students have more skilled than those who had never done as in the first experiment. Singer and Pease (1978) explains in their study how these factors influence the guidance in the process of guided discovery. Students were on assignment at the originally guided in doing a performance with the guidance will show significant results and efficient in maintaining the skills they had on subsequent assignments (retention).

This study also assesses the affective aspects of students are discipline and communicative. In the first cycle of success category affective student learning outcomes is still at the stage deficient, while in the second cycle affective learning outcomes of students already at a good level. The good Increasing cannot separated of the researcher's planning at the beginning of the second cycle to further intensify the guidance of teacher to groups in the investigation, especially when doing an experiment to be more disciplined in their work and when there are group discussions and class discussion, one group was given a chance to present the results while others respond. Teacher only as a mediator of learning guide this discussion to be more focused and get the concept that investigated at the end of the study. Referring to the research Salu (2013) which explains that the implementation strategy guided discovery, the teacher gives students the chance to practice and learn selfrespect, self-motivated and easier to transfer, minimize or avoid memorizing and students are responsible for their own learning.

The increase occurred in all student activity observed by the observer. This suggests that teacher activities to do in each phase that has been planned at the beginning of the cycle is going well. Activities in the orient teacher, organizing, guiding, directing and evaluating greatly assist students in the process of discovery. Students are not scientists and something they encountered that is whole new for the students, so that the user or teacher instruction is required of students (Adam, 2009). Referring research Çetin (2004) that the application of the model of the dicovery is able to encourage students to participate fully in the investigation and relate them to things that are contextual.

Student activity also increased because of the role of media in accordance with the needs of students. Media used in the first meeting to orient students to the problem is English video that are very difficult to be understood by students. Seeing such circumstances, the teacher then reflect the results of the first meeting with the attempt to change the video more easily understood and attractive to students for use in the second meeting. The result seen a significant increase in the activity of students in the second meeting. 
According to Kozma and Russell (1997) multimedia can assist students in connecting the various representations together. Representation is the meaning of an abstract into something concrete that is usually represented by symbols or symbolic. Students are taught to understand first the concept of buffer solution and non-buffer in early learning and connected with the next concept is $\mathrm{pH}$ buffer solution with the help of visual multimedia. The abstract concepts or ideas will be easierto be constructed with the help of multimedia visual tool that can be represented in the form of symbols so as to increase the knowledge of students, especially students of cognitive domains.

Based on calculations response given by 21 students of XI IPA 1 SMA Muhammadiyah Banjarmasin to the learning process by using model-assisted guided discovery macromedia flash on the material of the buffer solution is known that the response of students that are in both categories with the percentage of positive responses reached $80.92 \%$. The positive response of students is reinforced by the results of interviews with some of the students that the outline can be drawn several key points including a student interested in getting things that are new and are actively involved in learning, learning in groups can help students inquire with their peers to understand better the material and making it easier for students to solve difficulties in learning, and the use of interactive media to make students better understand the material, especially chemistry lesson buffer solution which is dominated by abstract. Students are more easily imagine what happens in a solution where chemical reactions occurring micro illustrated through a display picture/video.

Increased activity of teacher by providing reinforcement in early learning and directional guidance without dominating the process of investigating the student took part managed to increase the active involvement of students to seek its own concept and calculation proves $\mathrm{pH}$ buffer solution independently drawn a positive impact on student responses. Students expressed an interest in learning and searching for answers themselves from curiosity to a problem or a concept not yet known. Teacher successfully implement a constructivism learning theory which states that knowledge is constructed in the minds of students, in this case the students seek meaning and will try to find a connection sequence in the events from the world of information they receive based on their experience (learning by experience).

This classroom action research works and the hypothesis that using guided discovery-aided model of macromedia flash can improve student learning outcomes in class XI IPA 1 SMA Muhammadiyah Banjarmasin on learning materials of buffer solution is acceptable. Learning outcome is accompanied by increased activity of teacher, increase student and a good response from the students to the learning process.

\section{Conclusion}

Based on the research that has been done in class XI IPA 1 SMA Muhammadiyah Banjarmasin academic year 2014/2015 can be concluded that:

1) Activities of teachers and students activity experienced a significant upward trend after a phase of reflection in cycle 1 and revised in cycle 2 with marked learning processes running optimally.

2) Improved student learning outcomes significantly in cycle 2 with the overall analysis the students are better able to answer questions about the algorithmic than conceptual.

3) Increasing process skills of students in the second cycle is based on the same learning process of every meeting so that students are getting used to being scientific.

4) Psychomotor skills students are assessed increased significantly because only a repetition of the previous cycle so that it will show a good performance in future learning (retention).

5) The affective aspect of an improvement in cycle 2 due to the more intensive and optimal guidance given by the teacher.

6) The use of Macromedia Flash assist students in imagining an abstract concept into a concrete form. It is characterized by the positive response given to the students overall learning process.

\section{Bibliography}

[1]. Achera, Luzviminda J., Rene R. Belecina, dan Marc D. Garvida. 2015. The Effect of Group Guided Discovery Approach on Theperformance of Students in Geometry. International Journal of Multidisciplinary Research and Modern Education (IJMRME), Volume I, Issue II, 2454-6119.

[2]. Adam, Yuliati. 2009. Upaya Meningkatkan Hasil Belajar Siswa Konsep Peluang Melalui Penerapan Model Pembelajaran Temuan Terbimbing Kelas XI IA SMA Negeri 3 Seram Barat. Cited by http://www.fkip.unidar.ac.id/wpcontent/uploads/2013/06/RangKumaN\%20_\%20juRnaL\%20(06-15-13-03-42-37).docx at June 17, 2016.

[3]. Alfieri, Louis, Patricia J. Brooks, Naomi J. Aldrich, dan Harriet R. Tenenbaum. 2011. Does Discovery-Based Instruction Enhance Learning? Journal of Educational Psychology, Vol. 103, No. 1, pages 1-18.

[4]. Arnas, Erwina Amalia Juita. 2012. Pengaruh Penggunaan Laboratorium Virtual Dan Laboratorium Real Terhadap Sikap Ilmiah Dan Hasil Belajar Kimia Siswa Sma Pada Pokok Bahasan Larutan Penyangga. Cited byhttp://digilib.unimed.ac.id/pengaruhpenggunaan-laboratorium-virtual-dan-laboratorium-real-terhadap-sikap-ilmiah-dan-hasil-belajar-kimia-siswa-sma-pada-pokokbahasan-larutan-penyangga-22868.html at November 16, 2016

[5]. Balım, A., G. 2009. The Effects of Discovery Learning on Students' Success and Inquiry Learning Skills. Egitim ArastirmalariEurasian Journal of Educational Research, 35, 1-20. 
[6]. Çetin, Yücel. 2004. Teaching Logarithm by Guided Discovery Learning And Real Life Applications. Thesis. The Department Of Secondary Science And Mathematics Bducation. Cited http://citeseerx.ist.psu.edu/viewdoc/download?doi=10.1.1.632.7610\&rep=rep1\&type=pdf. at November 7, 2016.

[7]. Gabel, D. L. 1998. The Complexity of Chemistry and Implications for Teaching. In B. J. Fraser and K. G. Tobin (Eds.), International Handbook of Science Education (pp. 233-248). Dordrecht, The Netherlands: Kluwer Academic Publishers.

[8]. Gilbert, J.K. dan D. Treagust. 2008. Multiple Representations in Chemical Education: Models and Modeling in Science Education. Dordrecht: Springer. pp. 251-283.

[9]. Gultepe, N., Yalcin Celik, A., dan Kilic, Z. 2013. Exploring Effects of High School Students' Mathematical Processing Skills and Conceptual Understanding of Chemical Concepts on Algorithmic Problem Solving. Australian Journal of Teacher Education, 38 (10).

[10]. Haláková, Zuzana dan Miroslav Prokša. 2007. Two Kinds of Conceptual Problems in Chemistry Teaching. Journal of Chemical Education, Vol. 84 No. 1.

[11]. Johnstone, A. H. 2000. Teaching of Chemistry - Logical or Psychological? Chemistry Education: Research and Practice, 1, 9-15.

[12]. Jumadi. 2013. Penerapan Pembelajaran Penemuan Terbimbing untuk Meningkatkan Hasil Belajar Matematika Bagi Siswa Kelas $\begin{array}{llllll}\text { VIII SMP } & \text { Negeri } & 9 & \text { Malang. } & \text { Cited }\end{array}$ online.um.ac.id/data/artikel/artikelDC63FDFA02E7182CD7F8B622252DAFC3.pdf at Juni 18, 2016.

[13]. Klahr, David dan Milena Nigam. 2004. The Equivalence of Learning Paths in Early Science Instruction: Effects of Direct Instruction and Discovery Learning. Research Article, Volume 15 No. 10. American Psychological Society.

[14]. Kozma, Robert B. dan Joel Russell. 1997. Multimedia and Understanding: Expert and Novice Responses to Different Representations of Chemical Phenomena. Journal of Research in Science Teaching Vol. 34, No. 9, pp. 949-968. Department of Chemistry, Oakland University: Michigan.

[15]. Mayer, Richard E. 2004. Should There Be a Three-Strikes Rule Against Pure Discovery Learning. American Psychologist. Vol. 59., No.1, 14-19.

[16]. Nurseto, Tejo. 2011. Membuat Media Pembelajaran Yang Menarik. Fakultas Ekonomi Universitas Negeri Yogyakarta. Jurnal Ekonomi \& Pendidikan, Volume 8 Nomor 1. Cited by http://journal.uny.ac.id/index.php /jep/article/viewFile/706/570 at July 9, 2016.

[17]. Osman, Kamisah dan Nur Suhaidah Sukor. 2013. Conceptual Understanding in Secondary School Chemistry: A Discussion of The Difficulties Experienced By Students. American Journal of Applied Sciences, 10 (5): 433-441.

[18]. Salu, Benyamin. 2013. Pengaruh Strategi Penemuan Terbimbing terhadap Motivasi dan Hasil Belajar IPA Siswa Kelas IV SDN Rantepao I Kabupaten Toraja Utara. Jurnal Pendidikan Sains, Volume 1, Nomor 1, Halaman 85-91. Cited by http://journal.um.ac.id/index.php/jps/article/viewFile/3975/807 at November 20, 2016.

[19]. Saefulbahri, A. 2015. The Influence of Learning Model Guided Findings of Student Learning Outcomes. International Journal of Scientific and Technology Research Volume 4, Issue 03.

[20]. Singer, Robert N., dan Dale Pease. 1978. Effect of Guided Vs. Discovery Learning Strategies on Initial Motor Task Learning, Transfer, and Retention, Research Quarterly. American Alliance for Health, Physical Education and Recreation, 49:2, $206-217$.

[21]. Sirham, Ghassan. 2007. Learning Difficulties in Chemistry: An Overview. Journal of Turkish Science Education, Volume 4, Issue 2, pp. 2-20, September 2007.

[22]. Stamovlasis, Dimitrios, dkk. 2005. Conceptual understanding versus algorithmic problem solving: Further evidence from a national chemistry examination. Chemistry Education Research and Practice, 6 (2), 104-118.

[23]. Sund, R. B. \& Throwbridge, L. W. 1973. Teaching Science by Inquiry in the Secondary School, $3^{\text {rd }}$ Ed. Columbus: Charles E. Merrill Publishing Company.

[24]. Suyidno, A. Jamal dan E. Susilowati. 2012. Strategi Belajar Mengajar: Pegangan bagi Pembelajar Kreatif, Kritis dan Inovatif. Banjarmasin:Microteaching FKIP UNLAM.

[25]. Treagust, David F. dan Gail Chittleborough. 2001. Chemistry: A Matter of Understanding Representations. Subject-Specific Instructional Methods and Activities. Published online: 08 Mar 2015; Volume 8, pages 239-267.

[26]. Victoria, F.F.K. dan Paul, A.E. 2014. Enhancing Students' Achievement, Interest and Retention in Chemistry Through an Integrated Teaching/Learning Approach. British Journal Of Education, Society and Behavioural Science, 4(12), 1653-1663.

[27]. Zoller, Uri dan David Pushkin. 2007. Matching Higher-Order Cognitive Skills (HOCS) promotion goals with problem-based laboratory practice in a freshman organic chemistry course. Chemistry Education Research and Practice, 8 (2), 153-171. 